\title{
Forum Privilegiatum Sebagai Wujud Peradilan yang Adil Bagi Masyarakat
}

\author{
Budi Sastra Panjaitan
}

DATA NASKAH

Masuk: 20 Juli 2017

Diterima: 17 Mei 2018

Terbit: 1 Juni 2018

KORESPONDEN PENULIS:

Fakultas Syari'ah dan Hukum UIN Sumatera Utara, Jl. Willem Iskandar Pasar V Telp. 6615683-6622925, Fax.6615683 Medan Estate 20371 Email:

budisastrapanjaitan@ yahoo.co.id

\begin{abstract}
This paper aims to find out whether the privilegatum forum is needed or not to bring about a fair justice for the community. The state provides fair recognition, guarantee, protection and legal certainty for everyone without distinction of ethnicity, religion or position, including the poor who are unable to have access to justice properly, but in reality justice is not easily obtained, including those who are economically is under. Justice is illustrated more easily by those with special standing as state officials. In order to realize the balance of law and balance the sense of justice in the community, it is time for the forum privilegatum made a permanent choice for state officials who commit criminal acts. Through the privilegatum forum, the dismissal and punishment of state officials committing crimes is committed through special court mechanisms. This special tribunal is the first and final courts whose decisions are final and binding. $K$ eywords: Justice, Forum Privilegiatum, State 0 fficials.
\end{abstract}

\section{ABSTRAK}

Tulisan ini bertujuan untuk mengetahui apakah forum privilegiatum dibutuhkan atau tidak untuk mewujudkan peradilan yang adil bagi masyarakat. N egara memberikan pengakuan, jaminan, perlindungan dan kepastian hukum yang adil bagi setiap orang tanpa membedakan suku, agama atau kedudukan, termasuk orang miskin yang tidak mampu harus mendapatkan akses keadilan dengan baik, namun dalam kenyataannya keadilan tidak dengan mudah didapatkan, termasuk mereka yang secara ekonomi berada di bawah. Keadilan tergambar lebih mudah didapat oleh mereka yang memiliki kedudukan khusus sebagai pejabat negara. Dalam rangka mewujudkan keseimbangan hukum dan keseimbangan rasa keadilan pada masyarakat, sudah saatnya forum privilegiatum dijadikan pilihan tetap bagi pejabat negara yang melakukan tindak pidana. M elalui 
forum privilegiatum, pemberhentian dan penghukuman terhadap pejabat negara yang melakukan tindak pidana dilakukan melalui mekanisme pengadilan khusus. Pengadilan khusus ini merupakan pengadilan tingkat pertama dan terakhir yang putusannya bersifat final dan mengikat.

K ata K unci: Keadilan, Privilegiatum, Pejabat N egara.

\section{PENDAHULUAN}

Undang-Undang Dasar Negara Republik Indonesia Tahun 1945 secara tegas menyatakan tujuan yang hendak dicapai Negara Indonesia adalah melindungi segenap bangsa Indonesia dan seluruh tumpah darah Indonesia dan untuk memajukan kesejahteraan umum, mencerdaskan kehidupan bangsa, dan ikut melaksanakan ketertiban dunia yang berdasarkan kemerdekaan, perdamaian abadi dan keadilan sosial. Dalam rangka mewujudkan tujuan tersebut di atas, "pemerintah diberikan kewenangan untuk ikut campur tangan dalam segala lapangan kehidupan masyarakat" (Utrecht, 1960: 32), salah satunya adalah dalam bidang penegakan hukum. Campur tangan pemerintah merupakan bagian dari tugas pelayan masyarakat (public service), yaitu "tugas pemerintah tidak hanya dibidang pemerintahan saja, melainkan juga melaksanakan kesejahteraan sosial dalam rangka mencapai tujuan negara yang dijalankan melalui pembangunan nasional" (Basah, 1997: 3).

Hukum memiliki peranan yang teramat penting dalam mewujudkan tujuan pembangunan nasional. "Isi hukum adalah ketentuan tentang pengaturan penciptaan kesejahteraan negara" (Salman, 2009: 44). Tanpa adanya hukum dapat dipastikan tujuan Negara Indonesia tidak akan pernah tercapai. "M asyarakat sendiri juga dibangun di atas fondasi hukum" (Rahardjo, 1980: 85). Hukum harus dijadikan sebagai panglima guna mencapai ketertiban sosial dan keadilan sosial (Poernomo, 1993: 91). Hukum merupakan prasarana mental masyarakat untuk mengaktualisasikan potensi kemanusiaan dan naluri sosial guna dapat berkehidupan secara aman dan bermartabat (Alkostar, 2000: 62). M elalui hukum, negara memberikan fasilitas untuk beraktifitas secara benar.

Hukum harus menjamin terciptanya keadilan sosial bagi seluruh rakyat Indonesia. Jika negara membiarkan terjadinya perbedaan sosial di tengah-tengah masyarakat, yang kuat menekan yang lemah atau yang kuat memperdayakan secara tidak benar pihak-pihak yang lemah, dengan sendirinya keadilan sosial tidak akan pernah terwujud, hukum yang berkeadilan pada semuanya tidak akan dapat ditegakkan sekalipun langit runtuh. Semenatra itu, cita-cita menjadikan lembaga peradilan yang mandiri dan berwibawa merupakan masalah serius, hal ini dikarenakan dalam prinsip supremasi konstitusi semua konflik hukum atas penafsiran terhadap norma hukum baik di lingkungan penyelenggara negara maupun yang terjadi di masyarakat (peristiwa hukum kongkrit) penyelesaiannya bermuara pada lembaga peradilan (Hoesein, 2013:20).

\section{RUMUSAN MASALAH}

Bertitik tolak dari uraian di atas, artikel ini akan membahas keberadaan forum privilegiatum sebagai sarana dalam mewujudkan rasa keadilan bagi masyarakat.

\section{PEMBAHASAN}

\section{A. Perlakuan Yang Sama Dihadapan \\ Hukum}

Hukum dibutuhkan untuk menegakkan kebenaran dan keadilan (truth and justice), terutama untuk menegakkan keadilan bagi semua pihak yang dapat diartikan memberikan sesuatu kepada yang berhak atau menempatkan sesuatu pada tempatnya, hukum dan keadilan adalah dua konsep yang berbeda (Asshiddiqie dan Safa'at, 2012:15), hukum yang dipisahkan dari keadilan merupakan hukum positif (Kelsen, 1961: 5).

"Apabila keadilan itu kemudian dikukuhkan ke dalam institusi yang namanya hukum, maka, seperti telah diuraikan di muka, institusi hukum itu harus mampu untuk menjadi saluran agar keadilan itu dapat diselenggarakan secara seksama dalam masyarakat" (Rahardjo, 2000: 118).

M elepaskan hukum dari keadilan cukup sulit dan bukan hal yang gampang karena secara politis akan terkait dengan bagaimana menciptakan hukum sebagai sebuah keadilan, sementara itu konsep keadilan bagi semua orang tidaklah 
sama. Kebutuhan dan keinginan setiap orang sangatlah berbeda, karenanya rasa adil juga berbeda bagi setiap orang, seperti misalnya keadilan yang diinginkan penggugat sangatlah berbeda dengan keadilan yang diinginkan tergugat.

Seandainya keadilan dimaknai sebagai sebuah kebutuhan maka akan tergambar kebahagiaan semua orang menunjukkan keadilan bagi semuanya. "Keadilan sosial adalah kebahagiaan sosial" (Kelsen,1961: 5-6). Dasar pijak pemberian keadilan adalah hak yang dimiliki, baik terkait dengan hak yang melekat sebagai individu manusia maupun hak yang muncul karena adanya hubungan hukum dalam kehidupan bermasyarakat (M ochtar, 2009: 3).

Negara hukum menghendaki kekuasaan peradilan yang merdeka yang tidak dipengaruhi oleh kekuatan lain yang akan mengakibatkan hakim menyimpang dari kewajiban menegakkan hukum, keadilan dan kebenaran (Manan, 2004: 24). Hukum memperlakukan sama kepada siapapun dan apapun kekuasaanya (Taher, 2010: 50). M elalui Pasal 28D Ayat (1) Undang-Undang Dasar Negara Republik Indonesia Tahun 1945 secara tegas dinyatakan "Setiap orang berhak atas pengakuan, jaminan, perlindungan, dan kepastian hukum yang adil serta perlakuan yang sama dihadapan hukum".

Negara memberikan pengakuan, jaminan, perlindungan dan kepastian hukum yang adil bagi setiap orang tanpa membedakan suku, agama atau kedudukan derajat hidupnya, termasuk orang miskin yang tidak mampu harus mendapatkan akses keadilan dengan baik. Pengakuan negara tersebut menjadi sangat penting dalam mewujudkan sistem hukum dan rasa keadilan masyarakat Indonesia. “Negara turut campur dan bertanggung jawab dalam upaya mengangkat harkat dan martabat manusia sebagai perwujudan perlindungan hukum" (Amarullah, 2007: 2).

Persamaan di hadapan hukum harus diiringi dengan berbagai kemudahan untuk mendapatkan keadilan sebagai sarana perlindungan terhadap hak asasi manusia. $M$ arjinalisasi kepentingan telah mengakibatkan institusi peradilan kehilangan kekuatan dan kepercayaannya di mata publik. Karena faktor moral, lembaga peradilan dianggap kurang mampu untuk menjalankan fungsinya dengan baik. Hukum bersubstansikan moral, dimana hukum harus mengedepankan kebaikan bagi yang berperkara (Zulaekhah, et al. 2013:217).

Akses terhadap kebenaran dan keadilan bagi kelompok masyarakat miskin dapat dikatakan hanya jargon kosong karena pada kenyataannya masyarakat miskin seringkali tidak dapat menikmati kebenaran dan keadilan dalam sistem peradilan. "Di satu sisi, akses kaum miskin terhadap keadilannya (access to justice) rentan terabaikan atau sengaja diabaikan. Di sisi lain, akses terhadap keadilan masih menjadi salah satu persoalan utama bagi banyak orang yang berurusan dengan hukum" (Chrisbiantoro, et al., 2014: 1).

Jumlah penduduk miskin yang tercatat pada September 2017 mencapai 26,58 juta orang (antaranews.com), sebagian besar masih sulit untuk mendapatkan keadilan. M asyarakat miskin begitu sulit mendapatkan keadilan tanpa adanya campur tangan dan bantuan dari negara (Napitupulu dan Jiwandono, 2014:4). Masyarakat miskin seringkali mengalami dan menyaksikan ketidakadilan dalam menggunakan prosedur penyelesaian sengketa yang bersifat formalistik, diskriminatif, korup, adanya imunitas yang dimiliki oleh pejabat tertentu, dan lamanya proses penyelesaian sengketa. Faktor-faktor semacam ini kemudian menyebabkan krirsis kepercayaan terhadap badan peradilan.

Karena sulitnya mendapatkan kebenaran dan keadilan khususnya bagi masyarakat miskin, maka tak heran kalau kemudian lahir pendapat yang menyatakan keadilan sudah menjadi barang mewah bagi masyarakat miskin. Realitas sosial menunjukkan meskipun negara menjamin persamaan setiap orang dihadapan hukum, namun kenyataannya keadilan tidak dengan mudah dapat diwujudkan karena banyaknya perbedaan dan kemampuan yang dimiliki setiap orang. Padahal, "hukum mempunyai tugas yang suci yakni memberi kepada setiap orang apa yang berhak diterima" (Arrasjid, 2004: 40).

Perbedaan perlakuan bukan hanya terletak pada proses penegakan hukum belaka, tetapi lebih dari itu dimulai sejak pembuatan peraturan yang sering kali hanya mewakili kepentingan kelompok masyarakat tertentu. Akibatnya perlakuan yang sama di hadapan hukum tidak dengan sendirinya dapat terwujud walaupun telah dijamin oleh Undang-Undang Dasar Negara Republik Indonesia Tahun 1945.

Bahkan bagi sebagian orang lembaga peradilan tidak 
sangat mudah untuk dapat diakses oleh pencari keadilan pada umumnya. Berikut ini beberapa faktor yang mengakibatkan lembaga peradilan tidak sangat mudah dapat diakses oleh pencari keadilan, yaitu: (1). Formalitas legalitas yang teramat kaku, (2). Tingkat pengetahuan masyarakat yang tidak memadai terhadap hukum acara, (3). Membosankan dan terlalu bertele-tele, (4). Hasil yang diharapkan tidak sebanding dengan penegakan keadilan, (5). Biaya relatif tidak murah bagi kebanyakan orang.

Lembaga peradilan yang seharusnya menjadi benteng terakhir (last fortress) untuk mendapat keadilan sering tidak mampu memberikan keadilan yang didambakan. Akibatnya, "rasa hormat dan kepercayaan terhadap lembaga peradilan nyaris tidak ada lagi sehingga semaksimal mungkin orang tidak menyerahkan persoalan hukum ke pengadilan" (Rahardjo, 2000: 110). Kekecewaan terhadap badan peradilan juga sangat dirasakan oleh masyarakat ketika dipertontonkan oknum pejabat korup yang diadili hanya dengan "hukuman ringan".

Jika dibiarkan warga negara yang mencari keadilan terhalang hanya karena formalitas, tidak jelas dan kabur, hal tersebut berarti "negara telah memisahkan primary rule dan secondary rule"(Pangaribuan, 2004: 27). Dengan begitu "keadilan tidak akan tercapai hanya karena aparatur dalam proses pendahuluan telah menjadi barrier"(Pangaribuan, 2004: 27). Berbagai usaha yang bertujuan untuk mendesain peradilan agar lebih efektif dan efisien dalam mewujudkan keadilan telah banyak dilakukan, tetapi sampai dengan sekarang belum membuahkan hasil yang sangat memuaskan.

Sudah seharusnya M ahkamah Agung sebagai badan peradilan tertinggi memberikan sanksi yang tegas terhadap oknum pejabat peradilan yang melakukan perbuatan tidak terpuji, dengan cara: memiskinkan oknum pejabat peradilan yang bersangkutan, mengumumkan kepada khalayakumum perihal perbuatan oknum yang bersangkutan, mencabut hak politik oknum pejabat peradilan yang bersangkutan, dan memberhentikan dengan tidak hormat oknum pejabat peradilan yang bersangkutan.

Penyelenggaraan keadilan secara benar kepada semua warga negara merupakan upaya untuk memenuhi dan sekaligus sebagai implementasi negara hukum yang mengakui dan melindungi serta menjamin hak asasi warga negara akan kebutuhan terhadap akses keadilan (access to justice) dan kesamaan di hadapan hukum (equality before the law).

\section{B. Forum Privilegiatum Sebagai Sarana Mewujudkan Rasa Keadilan}

Hukum dan penegakan hukum merupakan bagian yang tidak bisa diabaikan begitu saja, jika diabaikan akan menyebabkan tidak tercapainya penegakan hukum yang diharapkan (Soekanto, 2013: 5). Pada hakikatnya eksistensi penegakan hukum di Indonesia adalah untuk mencapai tujuan hukum, yakni kepastian hukum, keadilan, dan kemanfaatan hukum bagi pencari keadilan (Effendy, 2005: 151).

Tujuan utama hukum adalah untuk mewujudkan ketertiban (order). Tujuan ini sejalan dengan fungsi utama hukum yang bersifat mengatur, memaksa dan memberikan sanksi. Ketertiban merupakan syarat mendasar yang sangat dibutuhkan oleh masyarakat. "Ketertiban adalah tujuan pokok dan pertama daripada segala hukum" (Kusumaatmadja, 1986: 2).

Penganut paradigma hukum alam berpendapat tujuan hukum untuk mewujudkan "keadilan" (Utrecht, 1975: 20). Menurut Aristoteles, kriteria keadilan dalam penafsiran hukum adalah epikeia, yaitu suatu rasa apa yang pantas (Hujibers, 1982: 29). Dalam perkembangannya keadilan bukanlah satu-satunya kata yang digunakan dalam mewujudkan tujuan hukum. Dalam negara hukum modern (welfare state) tujuan hukum adalah untuk mewujudkan "kesejahteraan" (Kusumaatmadja, 1986: 3). Untuk mencapai hasil yang adil dalam menyelesaikan sengketa haruslah ditetapkan prosedur atau cara yang adil (just procedures) (Gie, 1979: 35). Ada dua aspek untuk mencapai penegakan hukum yang adil, yaitu tata cara yang adil (procedure justice) dan isi atau hasil yang adil (substantive justice) (Manan, 2005: 10).

Gangguan dalam penegakan hukum akan terjadi apabila kemudian tidak terdapat keserasian antara kaidah hukum dengan perilaku manusia. Dalam konteks yang demikian dibutuhkan peran yang nyata dan tidak memihak dari aparat penegak hukum dalam menegakkan hukum demi terwujudnya keadilan. Guna mewujudkan rule of the law dibutuhkan hak yang sama bagi setiap orang di hadapan 
hukum. M elalui persamaan hak di hadapan hukum (equality before the law), semua orang dari yang kaya sampai yang miskin, dari yang bermartabat sampai dengan yang tidak bermartabat, dan dari yang lengkap fisik dan fsikisnya maupun yang tidak lengkap fisik dan fsikisnya memiliki hak yang sama di hadapan hukum tanpa ada kecuali dalam menggapai keadilan (acces to justice).

Persamaan di hadapan hukum atau equality before the law adalah salah satu asas terpenting dalam hukum modern (M ohamed, 1998: 62), dan asas ini merupakan prasyarat sebuah negara hukum (llyas, 1996: 15). Persamaan di hadapan hukum menjadi salah satu doktrin hukum dalam rule of law yang juga menyebar pada negara-negara berkembang seperti Indonesia. Persamaan di hadapan hukum harus dimaknai secara dinamis dan tidak dimaknai secara statis. Jika persamaan di hadapan hukum dimaknai secara statis, dengan sendirinya akan melahirkan ketidakadilan yang dilahirkan dari perbuatan menodai persamaan di hadapan hukum, akibatnya kemudian secara struktur telah terjadi perbuatan yang mengingkari equality before the law.

Persamaan di hadapan hukum harus diimbangi dengan perbuatan yang berupa persamaan perlakuan (equal treatment) bagi semua orang. Jika kemudian datang para pihak yang bersengketa ke hadapan hakim, maka hakim harus memperlakukan sama terhadap mereka (audi et alteram partem) sekalipun yang datang tersebut seorang jenderal dan seorang petani miskin. Jika kemudian hakim sudah bertindak tidak melakukan perlakuan yang sama terhadap mereka, berarti hakim yang bersangkutan tidak lagi mewujudkan badan peradilan sebagai benteng terakhir tertip hukum (the last bastion of legal order).

Dengan adanya penegakan hukum dan persamaan di hadapan hukum yang dimaknai secara dinamis, berarti jaminan untuk memperoleh keadilan (access to justice) bagi semua orang tanpa memperdulikan latar belakang para pihak yang bersengketa sehingga kebenaran dan keadilan (truth and justice) serta hukum sebagai agent of change dapat terwujud secara pasti.

Dalam praktek, persamaan di hadapan hukum sering dimaknai secara statis, hal ini terlihat secara gamblang tatkala yang berhadapan dengan hukum adalah masyarakat biasa, akan berbeda kemudian yang berhadapan dengan hukum adalah pejabat negara. Akibatnya rasa keadilan dan persamaan di hadapan hukum menjadi ibarat "langit dengan tanah".

Hampir dapat dikatakan begitu sangat sulit masyarakat biasa untuk menggapai keadilan, sementara pejabat negara yang "hidup" dengan uang dan fasilitas dari rakyat hampir dapat dikatakan begitu gampang untuk mengakses keadilan. Seolah-olah tergambar jika pejabat negara menjadi warga negara kelas satu dalam mengakses keadilan, jika hal ini terus berlanjut sama artinya dengan menempatkan rakyat pada posisi yang lemah dan rawan terhadap keadilan.

“Prinsip persamaan berarti semua manusia sama, harus diperlakukan sama, tidak boleh mengutamakan suatu golongan, semua manusia mempunyai kesempatan dalam setiap kesempatan yang ada. Perbedaan manusia yang satu dengan yang lainnya hanyalah didasarkan kepada ketakwaan kepada al-Khaliq Allah SWT". (Qamar, 2013: 37)

Dalam rangka mewujudkan prinsip persamaan dan rasa keadilan, segala sikap dan tindakan diskriminatif antara masyarakat dengan pejabat negara adalah perbuatan terlarang, terlebih-lebih perbuatan yang kemudian dapat mengakibatkan terhambatnya proses hukum. Lembaga peradilanpun semakin terpuruk karena tidak mampu mengangkat keadilan antara rakyat dengan pejabat negara. Dengan adanya proses yang berbeda dalam penegakan hukum terhadap pejabat negara seolah-olah menunjukkan adanya intervensi terhadap kekuasaan kehakiman, padahal Pasal 3 ayat (2) Undang-Undang Nomor 48 Tahun 2009 tentang Kekuasaan Kehakiman secara tegas menyebutkan "segala campur tangan dalam urusan peradilan oleh pihak lain di luar kekuasaan kehakiman dilarang".

Tindakan yang secara nyata membatasi gerak peradilan dalam menegakkan hukum, khususnya kepada pejabat negara karena adanya prosedur tertentu yang memberikan hak imunitas telah menunjukkan dengan sengaja membedakan setiap orang di hadapan hukum, prosedur dimaksud dapat ditafsirkan sebagai bentuk campur tangan dalam urusan peradilan oleh pihak lain di luar kekuasaan kehakiman yang berujung kepada diskriminasi.

Keistimewaan dalam bentuk prosedur tertentu terhadap 
pejabat negara dapat dimaknai sebagai bentuk perlawanan terhadap Pasal 27 ayat (1) dan Pasal 281 ayat (2) UndangUndang Dasar Negara Republik Indonesia Tahun 1945. A kibatnya cita-cita negara hukum (rechtsstaat) terabaikan karena adanya prosedur khusus dimaksud. Proses penegakan hukum terhadap pejabat negara seharusnya tidak mengandung diskriminasi dengan rakyat biasa yang berpotensi bertentangan dengan prinsip equal protecition yang dijamin oleh Pasal 27 ayat (1) dan Pasal 28D ayat (3) Undang-Undang Dasar Negara Republik Indonesia Tahun 1945, yaitu persamaan atau kesederajatan dihadapan hukum dan pemerintahan.

Sekalipun hak imunitas diperlukan bagi pejabat negara, bukan berarti dalam tindakan kehakiman hak imunitas harus melekat. Jika hak imunitas melekat sama artinya asas proporsionalitas telah terabaikan, karena menunda proses kehakiman dengan alasan adanya prosedur tertentu terhadap pejabat negara telah menunjukkan terjadinya pembatasan kesetaraan di hadapan hukum, yang berarti telah terjadi diskriminasi antara rakyat dengan pejabat negara.

"Namun demikian, adanya pembedaan itu harus berdasarkan prinsip logika hukum yang wajar dan proporsional yang secara eksplisit dimuat dalam undangundang serta tidak diartikan sebagai pemberian keistimewaan yang berlebihan. Meskipun memang diperlukan adanya perlakuan yang berbeda untuk menjaga independensi dan imparsialitas lembaga negara dan pejabat negara, namun perlakuan demikian tidak boleh bertentangan dengan prinsip negara hukum dan asas-asas peradilan pidana, apalagi sampai berakibat pada terhambatnya proses hukum". (Putusan MK Nomor 76/PUU-XII/2014; 105)

Proses peradilan yang dipolitisasi melalui prosedur tertentu telah mengakibatkan hukum yang seharusnya superior kepada siapapun dikesampingkan dan pada akhirnya menghambat proses hukum, tindakan demikian berarti telah menunjukkan ketidaksesuaian dengan Pasal 5 dan Pasal 17 Undang-Undang Nomor 39 Tahun 1999 Tentang Hak Asasi Manusia.

Untuk mewujudkan keseimbangan hukum dan keseimbangan rasa keadilan pada masyarakat, sudah saatnya pengadilan khusus atau yang kerap dikenal dengan istilah forum privilegiatum dijadikan pilihan tetap bagi pejabat negara yang melakukan tindak pidana. Melalui forum privilegiatum, pemberhentian dan penghukuman terhadap pejabat negara yang melakukan tindak pidana dilakukan melalui mekanisme pengadilan khusus. Pengadilan khusus ini merupakan pengadilan tingkat pertama dan terakhir yang putusannya bersifat final dan mengikat.

Forum privilegiatum diadakan karena sesuai dengan tuntutan perkembangan jaman untuk mewujudkan rasa keadilan antara rakyat dengan pejabat negara, khususnya dalam memutus kejahatan pada tingkat pertama dan terakhir bagi pejabat negara. M ekanisme peradilan dalam pengadilan khusus ini dipercepat tanpa melalui jenjang pemeriksaan konvensional dari tingkat bawah sebagaimana yang dilakukan dalam pengadilan pada umumnya (Saleh dan Mukhlish, 2010: 41).

"Skema yang ideal yang perlu dipertimbangkan adalah dikembalikannya forum privilegiatum dalam hukum Indonesia. Perlu ada prosedur yang dipercepat, terbuka, dan dapat dipertanggungjawabkan agar pejabat-pejabat negara tetap dapat menjalakan tugasnya sebagai pejabat negara tanpa melanggar prinsip kesamaan kedudukan dihadapan hukum dan independensi kekuasaan kehakiman". (Putusan MK No. 76/PUU-XII/2014; 28)

Forum privilegiatum diperlukan dengan berbagai pertimbangan sebagai berikut: penyidikan dan penuntutan dilakukan secara khusus; proses persidangan berjalan secara cepat, fair, impartial, final dan mengikat; dan tidak ada proses banding, kasasi dan peninjauan kembali. Obyek kejahatan atau pelanggaran yang dapat diadili terhadap pejabat negara adalah kejahatan berat, yaitu kejahatan yang diancam tuntutan hukuman lima tahun atau lebih. Seandainya pejabat negara yang bersangkutan telah berhenti dari jabatannya, kejahatan atau pelanggaran yang dilakukan diadili di pengadilan biasa, mulai dari tingkat peradilan pertama, peradilan banding, hingga peradilan kasasi dan peninjauan kembali.

“Terdapat dua mantan menteri yang pernah disidang berdasarkan forum previligiatum ini yaitu Sultan Hamid II dan Mr. Djodi Gondokusumo. Dalam putusannya kedua 
mantan menteri ini diputus bersalah dan dijatuhi hukuman pidana masing-masing 10 (sepuluh) tahun penjara bagi Sultan Hamid II dan 1 (satu) tahun penjara bagi M r. Djodi Gondokusumo" (Zoelva, 2011: 90).

Dalam sejarah ketatanegaraan Republik Indonesia, forum previligiatum pernah diterapkan sebagaimana dianut dalam Konstitusi Republik Indonesia Serikat Tahun 1949 dan Undang-Undang Dasar Sementara Tahun 1950. Pada Pasal 148 Konstitusi Republik Indonesia Serikat Tahun 1949 dan Pasal 106 ayat (1) Undang-Undang Dasar Sementara Tahun 1950, memberikan kewenangan kepada M ahkamah Agung sebagai pengadilan khusus untuk mengadili presiden, wakil presiden, dan pejabat negara lainnya yang telah melakukan kejahatan dan pelanggaran jabatan serta kejahatan dan pelanggaran lain yang ditentukan dalam undang-undang dalam masa jabatannya.

Guna memperkuat posisi forum privilegiatum, maka perlu dilakukan penataan terhadap kewenangan Mahkamah Agung. Selanjutnya forum privilegiatum harus berani mengambil sikap tegas dengan cara: memberikan hukuman maksimal terhadap pejabat negara yang terbukti melakukan tindak pidana; memulihkan harkat dan martabat serta kedudukan pejabat negara yang bersangkutan apabila kemudian tidak terbukti melakukan tindak pidana; mencabut hak politik yang bersangkutan apabil terbukti melakukan tindak pidana; memiskinkan oknum pejabat negara yang bersangkutan apabila terbukti melakukan tindak pidana; mengumumkan secara terbuka perihal hukuman yang diterima oleh oknum pejabat negara yang bersangkutan; membatasi diri dari kewenangan untuk memeriksa perkara banding, kasasi dan peninjauan kembali yang dimohonkan oleh oknum pejabat yang dipidana tersebut.

\section{KESIM PULAN}

Guna mengimplementasikan negara hukum dan melindungi segenap lapisan masyarakat, keadilan harus dijalankan secara utuh tanpa membedakan latar belakang personal yang bersangkutan. Hak imunitas bagi pejabat negara justru menjadikan peradilan tidak agung dan menggambarkan ada perbedaan dalam mewujudkan keadilan antara yang miskin dengan pejabat negara.

Lahirnya peradilan yang agung dalam mewujudkan keadilan merupakan political will negara untuk mewujudkan persamaan perlakuan di hadapan hukum. Peradilan yang agung paling tidak dapat diwujudkan melalui forum privilegiatum, penghukuman bagi pejabat negara yang melakukan tindak pidana berat tidak perlu dilakukan melalaui peradilan biasa, tetapi langsung melalui forum privilegiatum sehingga rasa keadilan bagi semua golongan menjadi sebuah kenyataan.

Dalam rangka mewujudkan peradilan yang agung, sebaiknya dilakukan penataan terhadap kewenangan Mahkamah Agung, penataan tersebut dengan menghadirkan kembali forum privilegiatum dalam memeriksa dan memutus tindak pidana yang dilakukan oleh pajabat negara sehingga persamaan hak di hadapan hukum (equality before the law) guna mewujudkan rasa keadilan secara nyata antara si miskin dan pejabat negara dapat terwujud.

\section{DAFTAR PUSTAKA}

\section{Buku:}

Alkostar., Artidjo, 2000, N egara Tanpa H ukum: C atatan Pengacara Jalanan, Yogyakarta: Pustaka Pelajar

Amarullah M. Arief, 2007, Politik H ukum Pidana Dalam Perlindungan Korban Kejahatan Ekonomi Di Bidang Perbankan, M alang: Banyumedia.

Arrasjid C hainur, 2004, D asar-D asar IImu H ukum, Jakarta, Sinar G rafika.

Asshiddiqie, Jimly dan M . A li Safa'at, 2012, Teori H ansK elsen Tentang H ukum, Jakarta: Konstitusi Press.

Basah, Sjachran, 1997, Eksistensi dan Tolak U kur Badan Peradilan Administrasi N egara di Indonesia, Bandung: Alumni.

Chrisbiantoro, M Nur Sholikin Satrio W irataru, 2014, Bantuan H ukum M asih Sulit Diakses: H asil Pemantauan D i L ima Provinsi Terkait Pelaksanaan U ndang-U ndang N 0. 16 Tahun 2011 Tentang B antuan H ukum, Jakarta: KontraS, PSHK dan AIPJ.

Effendy, M arwan, 2005, K ejaksaan Republik Indonesia, Posisi dan Fungsinya D ari Perspektif H ukum, Jakarta: Gramedia Pustaka U tama

Gie, The Liang, 1979, Teori-Teori K eadilan, Yogyakarta: Super

H ujibers Theo, 1982, Filsafat H ukum D alam L intasan Sejarah, Jakarta: Pustaka Filsafat

Ilyas, Karni, 1996, Catatan H ukum, Jakarta: Yayasan Karyawan Forum. 
Kelsen $\mathrm{H}$ ans, 1961, General Theory of Law and State, translated by: Anders W edberg, Russell \& Russell, N ew York Kusumaatmadja, M uchtar, 1986, Fungsi dan Perkembangan H ukum D alam Pembangunan N asional, Bandung: Lembaga Penelitian Hukum Dan Kriminologi Fakultas Hukum U niversitas Padjadjaran

M anan Bagir, 200, Teori dan Politik Konstitusi, Yogyakarta: FH UII Press

M D. M oh. Mahfud, 1998, Politik H ukum Di Indonesia, Jakarta: Pustaka LP3ES Indonesia

Napitupulu Erasmus A.T. dan Pascalis Jiwandono, 2014, Komentar A tas Bantuan H ukum D alam Rancangan K U H AP, Jakarta: Institute for C riminal Justice R eform,

Poernomo Bambang, 1993, Pola Dasar Teori A zas U mum H ukum A cara Pidana Dan Penegakan Hukum Pidana, Yogyakarta, Liberty.

Q amar Nurul, 2013, H ak A sasi M anusia Dalam negara H ukum D emokrasi, Jakarta: Sinar G rafika

Rahardjo Satjipto, 2000, IImu H ukum, Bandung, CitraA ditya Bakti.

Salman R.H . O tje, 2009, Filsafat H ukum (Perkembangan \& Dinamika M asalah), Bandung: R efika A ditama

Soekanto Soerjono, 2013, Faktor-Faktor yang M empengaruhi Penegakan H ukum, Jakarta: RajaG rafindo Persada

Taher Heri, 2010, Proses Hukum Yang A dil Dalam Sistem Peradilan Pidana di Indonesia, Yogyakarta, LaksBang Pressindo

U trecht E., 1975, Pengantar D alam H ukum Indonesia, Jakarta: Ikhtiar Baru

Waluyadi, 2009, K ejahatan, Pengadilan dan H ukum Pidana, Bandung: $\mathrm{M}$ andar $\mathrm{M}$ aju

Zoelva H amdan, 2011, Pemakzulan Presiden di Indonesia, Jakarta: Sinar G rafika.

\section{Jurnal}

Manan Bagir, 2005, Penegakan H ukum Yang Berkeadilan, M ajalah Varia Peradilan, N omor: 241

Pangaribuan Luhut M P.,2004, Interpretasi Pihak K etiga Yang B erkepentingan D alam Praperadilan Tindak Pidana K orupsi, Dictum Kajian Putusan Pengadilan, Edisi 2

Zulaekhah Siti, et.al., 2013, Rekonstruksi N orma Pencegahan dan Pnanggulangan PlagiarismeSebagai B entuk Perlindungan H ukum Bagi PenulisA kademik, Jurnal M edia Hukum, Vol. 20, No. 2

Zainal A rifin H oesein, Lembaga Peradilan D alam Perspektif Pembaruan H ukum, Jurnal M edia H ukum Vol 20, No 1 (2013)
Makalah

M ochtar M. Akil, 2009, Bantuan H ukum Sebagai Hak Konstitusional Warga Negara, Makalah Pada Karya Latihan Bantuan Hukum (KALABAHU)

\section{Internet}

Antaranews.com, "Jumlah penduduk miskin Indonesia 26,58 juta orang" https:/ / www.antaranews.com/ berita/ 674750/ jumlah-penduduk-miskin-indonesia-2658jutaorang, diunduh pada hari Sabtu, 19 M ei 2018, jam 10.15 WIB

\section{Peraturan Perundang-Undangan}

U ndang-U ndang D asar N egara Republik Indonesia Tahun 1945

U ndang-U ndang Dasar Sementara Tahun 1950

Undang-Undang Nomor 48 Tahun 2009 tentang Kekuasaan Kehakiman

U ndang-U ndang Nomor 39 Tahun 1999 Tentang Hak A sasi M anusia

\section{Putusan}

Putusan Mahkamah Konstitusi Nomor 76/ PU U -XII/ 2014 